\title{
A RELATION OF SERUM HOMOCYSTEINE AND URIC ACID IN BOSNIAN DIABETIC PATIENTS WITH ACUTE MYOCARDIAL INFARCTION
}

\section{ODNOS SERUMSKOG HOMOCISTEINA I MOKRAĆNE KISELINE KOD PACIJENATA SA DIJABETESOM I AKUTNIM INFARKTOM MIOKARDA IZ BOSNE I HERCEGOVINE}

\author{
Marijana Marković Boras ${ }^{1}$, Adlija Čaušević ${ }^{2}$ Marina Ćurlin ${ }^{3}$ \\ ${ }^{1}$ Department of Laboratory Medicine, University Clinical Hospital Mostar, Mostar, Bosnia and Herzegovina \\ ${ }^{2}$ Department of Biochemistry and Clinical Analysis, Faculty of Pharmacy, \\ University of Sarajevo, Sarajevo, Bosnia and Herzegovina \\ ${ }^{3}$ Faculty of Health Studies, University of Mostar, Mostar, Bosnia and Herzegovina
}

\section{Summary}

Background: Coronary artery disease as a consequence of atherosclerosis is the most common cause of morbidity and mortality in type 2 Diabetes Mellitus (DM) patients. Homocysteine (HCY), as one of the risk factors, and uric acid (UA) as the most common antioxidant in serum have their roles in the processes of inflammation and atherogenesis, which underlie the pathogenesis of acute myocardial infarction (AMI). The effect of HCY in cardiovascular disease is thought to be manifested primarily through oxidative damage, implying a potential correlation between the $\mathrm{HCY}$ level and antioxidant status. Since the data related to the diagnostic significance of both HCY and UA in diabetic patients with $\mathrm{AMI}$ are conflicting, and so far not reported in Bosnian patients, this research aimed to examine the association of $\mathrm{HCY}$ and UA levels with glomerular filtration rate (eGFR) and explore the pathophysiological significance of these data in Bosnian diabetic patients with AMI.

Methods: This prospective research included 52 DM type 2 patients diagnosed with AMI. Blood samples were taken on admission and used for biochemical analysis. Results of the biochemical analyses were statistically analysed.

Results: Elevated HCY and UA levels were observed in diabetic patients. Females have higher HCY compared to males. A positive correlation was revealed between $\mathrm{HCY}$ and UA and was confirmed with different HCY levels in subgroups with different UA level. A negative correlation

\section{Kratak sadržaj}

Uvod: Bolest koronarnih arterija kao posledica ateroskleroze je najčešći uzrok morbiditeta i mortaliteta kod pacijenata sa dijabetesom melitus tipa 2 (DM). Homocistein (HCY), kao jedan od faktora rizika, i mokraćna kiselina (UA), kao najčešći antioksidans u serumu, imaju svoju ulogu u procesima upale i aterogeneze koji su u osnovi patogeneze akutnog infarkta miokarda (AMI). Smatra se da se efekat HCY na kardiovaskularne bolesti manifestuje prvenstveno kroz oksidativno oštećenje, implicirajući potencijalnu korelaciju između koncentracije HCY i antioksidativnog statusa. Budući da su podaci koji se odnose na dijagnostički značaj HCY i UA kod dijabetičara sa AMI oprečni, i da do sada nisu nisu bili dostupni za pacijenate iz Bosne i Hercegovine, cilj ovog istraživanja je bio da se ispita povezanost koncentracije HCY i UA sa stopom glomerularne filtracije (eGFR) i istraži patofiziološki značaj ovih podataka kod pacijenata iz Bosne i Hercegovine koji su dijabetičari sa AMI.

Metode: Ovim prospektivnim istraživanjem obuhvaćena su 52 pacijenta sa dijabetesom tipa 2 kojima je dijagnostikovan AMI. Uzorci krvi su uzeti prilikom prijema pacijenata i korišćeni su za biohemijsku analizu. Rezultati biohemijskih analiza su statistički analizirani.

Rezultati: Primećeni su povišene koncentracije HCY i UA kod dijabetičara. Žene imaju veći $H C Y$ u poređenju sa muškarcima. Otkrivena je pozitivna korelacija između HCY
Address for correspondence:

Marijana Marković Boras

Kralja Tvrtka Street, 88000 Mostar, Bosnia and Herzegovina Phone: +38736341 921; Fax: +38736341954

e-mail: marijana.m.boras@gmail.com
List of abbreviations: DM, diabetes mellitus; CVD, cardiovascular disease; AMI, acute myocardial infarction; STEMI, ST-segment elevation myocardial infarction; $\mathrm{HCY}$, homocysteine; UA, uric acid; $\mathrm{PCl}$, percutaneous coronary intervention; $\mathrm{NO}$, nitric oxide; ECG, electrocardiogram; IFCC, International Federation of Clinical Chemistry. 
was observed between UA and $\mathrm{HbA} 1 \mathrm{c}$, as well as between both HCY and UA with eGFR.

Conclusions: These results contribute to the clarification of the biochemical mechanisms characteristic in AMI patients with DM. According to these results, we believe that joint measurement of HCY and UA could enable a better assessment of the prognosis for this group of patients. This kind of assessment, as well as regression analysis, can identify high-risk patients at an earlier stage when appropriate interventions can influence a better outcome in such patients.

Keywords: diabetes mellitus type 2, homocysteine, myocardial infarction, uric acid

\section{Introduction}

Acute myocardial infarction (AMI), occurs as a result of atherosclerotic plaque rupture and formation of thrombus. Myocardial tissue becomes inflamed and necrotic; it loses contraction and impulse conducting ability with the net result of decreased oxygen distribution and irreversible damage to the heart muscle (1).

Cardiovascular disease (CVD) and AMI are the most common causes of morbidity and mortality in patients with Diabetes Mellitus (DM) (2). They have two to four times higher mortality due to $A M I$ and stroke compared to patients of the same age without DM. The mortality rate is between one and three times higher in males and between two and five times higher in females than the control group without diabetes (3). In the post-infarction period, mortality is significantly more frequent in patients with DM.

Novel studies of CVD risk factors in patients with diabetes indicate the diagnostic value of elevated homocysteine (HCY) and uric acid (UA) levels. An increased level of $\mathrm{HCY}$ in $\mathrm{AMI}$ patients compared to the group of healthy subjects was observed in the previous research $(4,5)$, while in some $(6)$, such association was not observed. Results of previous research related to the possible relationship between $\mathrm{HCY}$ and DM show a high degree of inconsistency. Some authors reported an association between increased HCY level in DM type 2 and insulin resistance (7) as well as an increased risk of vascular disease, while others found a decreased level of HCY in diabetics (8) or no difference in $\mathrm{HCY}$ level between diabetics and healthy subjects (9). It is believed that hyperhomocysteinemia may be the cause and/or the consequence of insulin resistance.

So far, it has been shown that serum UA levels are elevated in patients with $\mathrm{AMI}$, involving categories belonging to patients with systemic hypertension and those with DM, when compared to healthy individuals. Diabetic patients who are hyperuricemic appear to be at increased risk of developing diabetic complications, especially renal and cardiovascular (10). Previous studies have reported that a high concentra- i UA i potvrđena je različitim koncentracijama HCY u podgrupama sa različitim nivoom UA. Negativna korelacija je primećena između UA i HbA1c, kao i između HCY i UA sa eGFR.

Zaključak: Ovi rezultati doprinose pojašnjenju biohemijskih mehanizama karakterističnih za $\mathrm{AMI}$ pacijente sa DM. Prema ovim rezultatima, verujemo da bi zajedničko merenje HCY i UA moglo da omogući bolju procenu prognoze za ovu grupu pacijenata. Ova vrsta procene, kao i regresiona analiza, mogu identifikovati visoko rizične pacijente u ranijoj fazi kada odgovarajuće intervencije mogu uticati na bolji ishod kod takvih pacijenata.

Ključne reči: diajbetes melitus tip 2, homocistein, infarkt miokarda, mokraćna kiselina

tion of UA is also a strong marker of an unfavourable prognosis of moderate to severe heart failure and CVD. Namely, hyperuricemia has a critical impact on poor outcome in AMI patients. Since the effect of both HCY and UA in CVD is thought to be primarily related to oxidative damage on the vascular endothelium, causing alterations in the vasodilatory properties of endothelial cells due to disturbances in nitric oxide (NO) bioavailability and scavenging (11), it was not a surprise to observe that joint effect of hyperhomocysteinemia and hyperuricaemia has a stronger effect on changes on the vascular endothelium (12).

Although $\mathrm{HCY}$ and UA have many similarities, their relation is not quite clear in diabetic patients with AMI. A detailed literature review indicated that at least so far there have been no studies trying to link the HCY level and compounds with antioxidant activity level, which are measured in routine clinical practice in percutaneous coronary intervention $(\mathrm{PCl})$. Therefore, the aim of this research is to elucidate the relation between laboratory markers, mainly $\mathrm{HCY}$ and UA levels, to correlate these results to glomerular filtration rate (eGFR) and to determine their significance in diabetic patients with AMI.

\section{Materials and Methods}

This prospective research included 52 DM type 2 patients diagnosed with AMI. Patients were admitted to the Department of Cardiology at the University Clinical Hospital of Mostar, Bosnia and Herzegovina, in the period between October 2016 and January 2019. Patients were previously diagnosed with DM type 2 based on ADA recommendations (13).

Study design, methods and statistical analysis are similar to our previous research published in August 2018 (14). The AMI diagnosis was made by a cardiologist on the basis of at least two of the three WHO criteria (1). All patients were diagnosed with STEMI myocardial infarction, before performance of $\mathrm{PCl}$ as a treatment method. STEMI was confirmed by electrocardiogram (ECG). Detailed medical history, including usual CVD risk factors, such as hypertension 
and smoking, was taken for each patient. Hypertension was defined as systolic arterial pressure $\geq 140$ $\mathrm{mmHg}$ and/or diastolic arterial pressure $\geq 90 \mathrm{mmHg}$ or as the use of antihypertensive drugs. Smoking was defined as daily consumption of at least one cigarette. Exclusion criteria were pregnancy, the use of antiepileptic, contraceptive therapy, cancer, and vitamin B12 supplementation in the last 6 months.

All participants in this research were informed about the details of the study. The research did not affect the treatment and hospitalisation duration of patients. It was done in accordance with ethical recommendations and practices of Mostar University Clinical Hospital and the Declaration of Helsinki.

Due to the simpler interpretation of possible statistically significant results, according to previous studies $(14,15)$ patients involved were divided by UA in tertiles and according to gender. In the correlation analysis, patients were stratified according to age, gender, smoking, hypertension, $\mathrm{UA}, \mathrm{HCY}, \mathrm{HbA} 1 \mathrm{c}$ and eGFR level as well.

On admission, after ECG, and before the PCl, venous blood samples were taken into the vacuum tubes. A serum sample used to determine the UA and $\mathrm{HCY}$ level was taken with one anticoagulant-free 7.5 $\mathrm{mL}$ test tube (Sarstedt, Germany). Whole blood sample for $\mathrm{HbA} 1 \mathrm{c}$ assay was taken in a single $2.6 \mathrm{~mL}$ test tube with EDTA as an anticoagulant (Sarstedt, Germany). Residual parts of the samples were taken for research after the completion of routine treatment ordered by a cardiologist. The level of the HCY $(\mu \mathrm{mol} / \mathrm{L})$ was measured in the serum by non-competitive immunoassay method on Architect ci8200 Integrated System analyser (Abbot, llinois, USA). The UA level was measured according to the standardised IFCC (International Federation of Clinical Chemistry) photometric method (uricase-POX) on the AU680 analyser (Beckman Coulter, California, USA). HbA1c was measured on the same analyser according to standardised IFCC method - immunoturbidimetry. The statistical analysis was performed by SPSS (SPSS Inc., Chicago, IL, U.S.A.). The Kolmogorov-Smirnov test tested an assessment of the normality of data. Correlations were tested by the nonparametric Spearman correlation. The nonparametric MannWhitney $U$ test tested the differences between UA and $\mathrm{HCY}$ level in different subgroups of patients. The comparison of $\mathrm{HCY}$ and $\mathrm{UA}$ with respective reference ranges was performed by one-sample t-test. KruskalWallis and $\chi^{2}$ tests were used in cases of comparison of more than two groups (stratification of patients according to UA level in tertiles). $\mathrm{P}<0.05$ was considered statistically significant.

\section{Results}

As represented in Table I, this study included 52 diabetic patients diagnosed with AMI. The median age was $64.20 \pm 9.57$ years; $60.75 \pm 6.98$ and $71.81 \pm 8.81$ years for males and females, respectively $(p<0.001)$. It consisted of 40 male $(77 \%)$ and 12 female $(23 \%)$ patients.

Hypertension was equally distributed between males and females $(65 \%(26)$ and $75 \%(9)$, respectively). The prevalence of smoking was $46 \%$ (24); with $55 \%(22)$ and $17 \%(2)$ in males and females, respectively. Further analyses revealed lower HCY level in males $(12.99 \pm 4.22 \mu \mathrm{mol} / \mathrm{L})$ compared to females $(16.94 \pm 5.30 \mu \mathrm{mol} / \mathrm{L})(p=0.042)$. Females had a lower eGFR $(p=0.004)$ level as well. A statistically significant difference in other measured parameters was not observed (Table I).

In order to compare HCY and UA levels with the healthy population, results were compared with gender-dependent reference ranges (Figures 1 and 2). A significantly increased $\mathrm{HCY}$ level was observed in

Table I Demographic characteristics and biochemical parameters level.

\begin{tabular}{|l|c|c|c|c|}
\hline Variable (No; \%) & All patients $(\mathrm{n}=52)$ & Males $(\mathrm{n}=40)$ & Females $(\mathrm{n}=12)$ & $\mathrm{p}$ \\
\hline Age (years) (mean \pm SD) & $64.20 \pm 9.57$ & $60.75 \pm 6.98$ & $71.81 \pm 8.81$ & $<0.001^{1}$ \\
\hline Gender (males) & - & $40(77)$ & $12(23)$ & $<0.001^{2}$ \\
\hline Smoking (yes) & $24(46)$ & $22(55)$ & $2(17)$ & \\
\hline Hypertension (yes) & $36(69)$ & $26(65)$ & $9(75)$ & \\
\hline Parameter (Mean \pm SD) & & & & \\
\hline Homocysteine, mmol/L & $14.29 \pm 5,21$ & $12.99 \pm 4.22$ & $16.94 \pm 5.30$ & $0.042^{3}$ \\
\hline Uric acid, mmol/L & $335.46 \pm 112,12$ & $341.89 \pm 116.93$ & $311.63 \pm 80.87$ & \\
\hline HbA1c, \% & $7.39 \pm 1.61$ & $7.51 \pm 1.64$ & $7.06 \pm 1.57$ & \\
\hline eGFR-60 mL/min/1.73 m ${ }^{2}$ & $72.54 \pm 15,15$ & $74.13 \pm 13.94$ & $62.37 \pm 13.56$ & $0.004^{1}$ \\
\hline
\end{tabular}

${ }^{1}$ t-test, ${ }^{2} \chi^{2}$ test, ${ }^{3}$ Mann-Whitney $U$ 


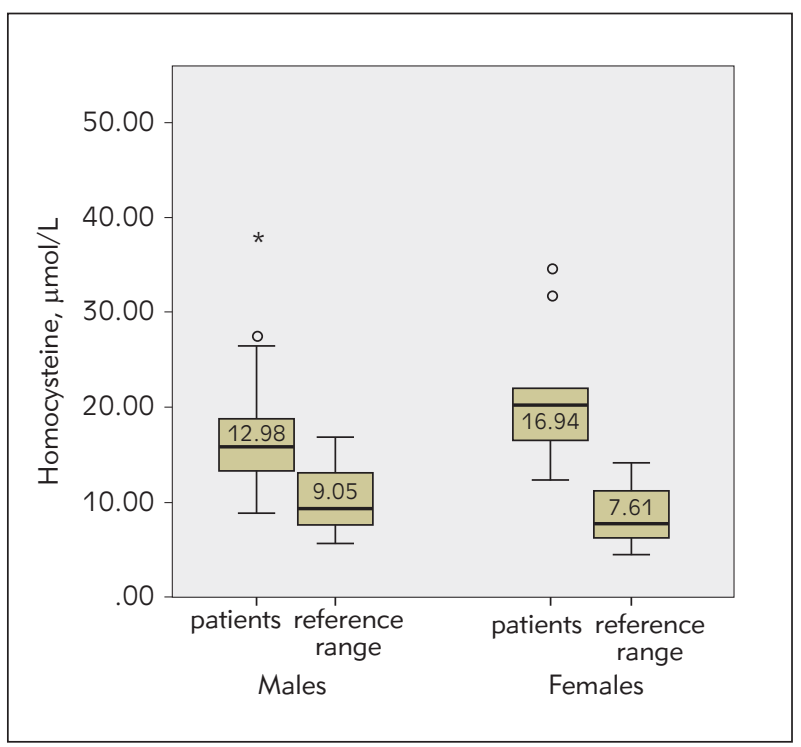

Figure 1 Comparison of homocysteine level with reference ranges for male and female patients. The graphs show the scatter of the results within the group. The thick black line in the middle is the median, inside the coloured area are the results between 25\% (lower edge) and 75\% (upper edge of the rectangle), i.e. $50 \%$ of all results, while the horizontal end lines indicate the range of results covering the largest and smallest results. They do not go beyond the framework of distribution (they are not outliers or extreme results). ( $p<0.001$ one-sample t-test).

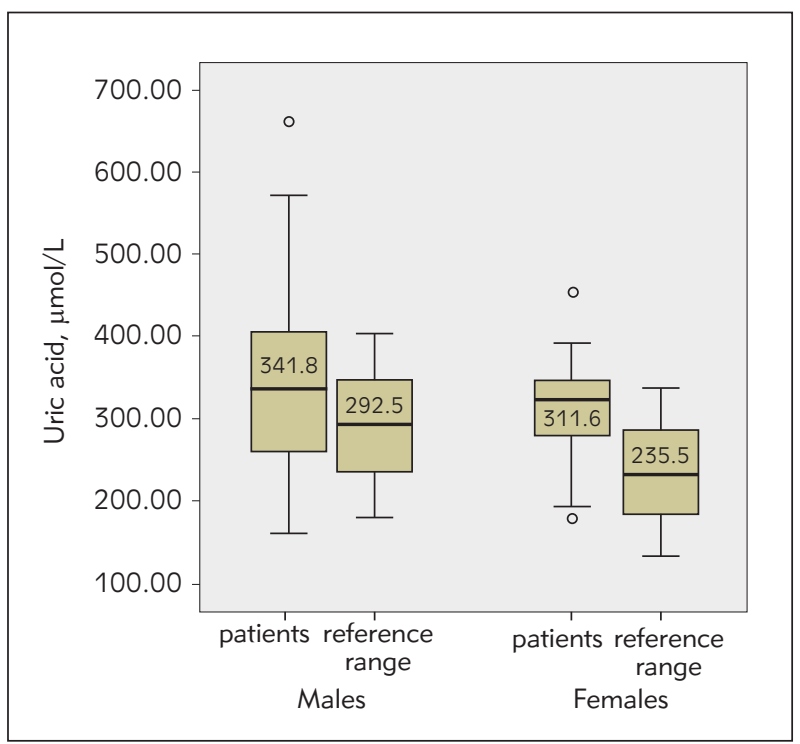

Figure 2 Comparison of UA level in gender-dependent subgroups with reference ranges. The graphs show the scatter of the results within the group for each variable. A thick black line in the middle of the rectangle indicates the mean value $(p<0.001$ t-test (one sample)).

Table II Distribution of patients according to Uric acid.

\begin{tabular}{|l|c|c|c|c|}
\hline \multicolumn{5}{|c|}{ Uric acid (mmol/L) } \\
\hline $\begin{array}{l}\text { Variable } \\
\text { (No; \%) }\end{array}$ & $\begin{array}{c}\text { Group 1 } \\
<272.0 \\
\mathrm{~N}=18\end{array}$ & $\begin{array}{c}\text { Group 2 } \\
272.0-356.0 \\
\mathrm{~N}=17\end{array}$ & $\begin{array}{c}\text { Group 3 } \\
>356.0 \\
\mathrm{~N}=17\end{array}$ & $\mathrm{P}$ \\
\hline Age (years) (mean $\pm \mathrm{SD}$ ) & $63.27 \pm 8.66$ & $65.93 \pm 9.51$ & $61.18 \pm 6.61$ & $0.283^{2}$ \\
\hline Gender (males) & $15(83 \%)$ & $10(59 \%)$ & $14(82 \%)$ & $0.185^{3}$ \\
\hline Smoking (yes) & $6(33 \%)$ & $10(58 \%)$ & $7(41 \%)$ & $0.519^{3}$ \\
\hline Hypertension (yes) & $7(38 \%)$ & $13(76 \%)$ & $15(88 \%)$ & $0.008^{3}$ \\
\hline Parameter (Mean $\pm \mathrm{SD})$ & & & & \\
\hline Homocysteine, mmol/L & $12.09 \pm 4.42$ & $17.17 \pm 6.62$ & $15.65 \pm 5.79$ & $0.030^{1}$ \\
\hline Uric acid, mmol/L & $229.37 \pm 33.93$ & $314.50 \pm 24.30$ & $464.43 \pm 86.17$ & $<0.001^{1}$ \\
\hline HbA1c, \% & $8.14 \pm 1.89$ & $7.00 \pm 1.04$ & $7.05 \pm 1.61$ & $0.091^{1}$ \\
\hline eGFR-60 mL/min/1.73m ${ }^{2}$ & $81.55 \pm 14.17$ & $68.77 \pm 10.99$ & $62.57 \pm 18.50$ & $0.003^{2}$ \\
\hline
\end{tabular}

${ }^{1}$ Kruskal-Wallis, ${ }^{2}$ ANOVA, ${ }^{3} \chi^{2}$ test

both male ( $p<0.001)$ and female $(p<0.001)$ patients compared to »normal« values within the reference range. The UA level was also compared with the gender-dependent reference range values. A significant increase in UA level was observed in both males $(p<0.001)$ and females $(p<0.001)$ com- pared to the "normal« values within the reference range.

The analysis of subgroups obtained by distribution according to the level of UA in tertiles revealed a reduced level of $\mathrm{HCY}$ in the first tertile, compared to the second and third $(p=0.030)$ (Table II). eGFR 
Table III The correlation analysis.

\begin{tabular}{|c|c|c|c|c|}
\hline \multirow{2}{*}{$\begin{array}{l}\text { Patient group } \\
\text { (No) }\end{array}$} & \multicolumn{4}{|c|}{ Spearman correlation $(p)$} \\
\hline & $\mathrm{HCY} / \mathrm{UA}$ & $\mathrm{HCY} / \mathrm{eGFR}$ & UA/eGFR & UA/HbA1c \\
\hline All patients (52) & rho $=0.298 p=0.03$ & rho $=-0.338 p=0.023$ & rho $=-0.525 p<0.001$ & rho $=-0.322 p=0.024$ \\
\hline \multicolumn{5}{|l|}{ Age (years) } \\
\hline$<55(10)$ & $p=0.139$ & $p=0.966$ & rho $=-0.565 / p=0.356$ & $p=0.460$ \\
\hline 55-65 (23) & $p=0.480$ & $p=0.145$ & rho $=-0.799 / p=0.009$ & $p=0.519$ \\
\hline$>65(19)$ & $p=0.062$ & $p=0.383$ & $\mathrm{p}<0.001$ & $p=0.180$ \\
\hline \multicolumn{5}{|l|}{ Gender } \\
\hline Males (40) & $p=0.101$ & $p=0.212$ & rho $=-0.556 / p=0.001$ & $p=0.090$ \\
\hline Females (12) & $p=0.110$ & $p=0.310$ & rho $=-0.685 / p=0.029$ & $p=0.055$ \\
\hline \multicolumn{5}{|l|}{ Smoking } \\
\hline Yes (24) & $p=0.345$ & $p=0.192$ & $p=0.078$ & $p=0.790$ \\
\hline No (28) & $p=0.715$ & $p=0.220$ & rho $=-0.644 / p=0.002$ & $p=0.376$ \\
\hline \multicolumn{5}{|l|}{ Hypertension } \\
\hline Yes (30) & $p=0.216$ & $p=0.140$ & rho $=-0.404 / p=0.030$ & $p=0.353$ \\
\hline No (22) & $p=0.260$ & $p=0.943$ & $p=0.655$ & $p=0.186$ \\
\hline \multicolumn{5}{|l|}{ Homocysteine } \\
\hline$<$ median value* $(26)$ & $p=0.300$ & $p=0.816$ & $p=0.134$ & $p=0.083$ \\
\hline$>$ median value* $(26)$ & $p=0.737$ & $p=0.113$ & rho $=-0.672 / p=0.001$ & $p=0.265$ \\
\hline \multicolumn{5}{|l|}{ Uric acid } \\
\hline$<272.0 \mathrm{mmol} / \mathrm{L}(18)$ & $p=0.713$ & $p=0.899$ & $p=0.703$ & $p=0.271$ \\
\hline $272.0-356.0 \mathrm{mmol} / \mathrm{L}(17)$ & $p=0.077$ & rho $=-0.574 / p=0.550$ & rho $=-0.509 / p=1.00$ & $p=0.795$ \\
\hline$>356.0 \mathrm{mmol} / \mathrm{L}(17)$ & $p=0.602$ & $p=0.020$ & $p=0.044$ & $p=0.473$ \\
\hline \multicolumn{5}{|l|}{$\mathrm{HbA1c}$} \\
\hline$<$ median value** (26) & $p=0.842$ & $p=0.099$ & $p=0.173$ & rho $=0453 / p=0.026$ \\
\hline$>$ median value ${ }^{* *}(26)$ & $p=0.134$ & $p=0.416$ & $p=0.094$ & $p=0.674$ \\
\hline \multicolumn{5}{|l|}{ eGFR } \\
\hline$<$ median value ${ }^{* * *}(26)$ & rho $=0.464 / p=0.0$ & rho $=-0.463 / p=0.023$ & $\mathrm{rho}=0.513 / p=0.010$ & $p=0.453$ \\
\hline$>$ median value ${ }^{* * *}(26)$ & $p=0.819$ & $p=0.186$ & $p=0.104$ & $p=0.195$ \\
\hline
\end{tabular}

${ }^{*}$ median value $13.56 \mu \mathrm{mol} / \mathrm{L}$

** median value $6.80 \%$

*** median value $70.660 \mathrm{~mL} / \mathrm{min} / 1.73 \mathrm{~m}^{2}$

shows a strong association with UA. Patients with lower eGFR values had significantly elevated serum UA level $(p=0.003)$. The incidence of hypertension was significantly higher in the third tertile with the highest level of UA (88\% (15)) compared to the first $(38 \%(7))$ and second (76 \% (13)) $(p=0.008)$ (Table II).
Correlation analyses in different subgroups are represented in Table III. In simple correlation analyses between UA and $\mathrm{HCY}$, a positive correlation occurred $(r h o=0.298)$. The same correlation was noticed in patients with eGFR value lower than the median value (rho=0.464). HCY shows negative correlation with eGFR (rho=-0.338). A correlation occurred in the third tertile of UA (rho=-0.574) and the subgroup 
with eGFR value lower than the median value ( $r$ ho=0.463 ) as well. A negative correlation was observed between eGFR and UA (rho=-0.525). A correlation was observed in the third tertile of UA ( $r$ ho $=-0.509)$ and an elevated HCY group (rho=-0.672). The correlation was strong in the elderly (rho $=-0.799$ ), as well as in patients with decreased eGFR (rho=0.513 ) and was present in nonsmokers and patients with hypertension as well (rho $=-0.644$ and rho $=-$ 0.404 , respectively). The correlation was moderate in both males (rho $=-0.556)$ and females (rho $=-0.685)$. A weak negative correlation was observed between $\mathrm{UA}$ and $\mathrm{HbA} 1 \mathrm{c}$ (rho=-0.322). In low HbA1c subgroup, a weak positive correlation occurred as well $(r h o=0.453)$. All mentioned correlations were at the level of significance $\mathrm{p}<0.05$ (Table III).

\section{Discussion}

Descriptive characteristics represented in Table I indicate a higher incidence of males compared to females in our study, i.e. the results of the research were obtained predominantly on the male population. The incidence of $77 \%$ of males is consistent with the previous research in which female patients were identified as less frequent but also as patients with a poorer prognosis after AMI (16).

Smoking, which is previously recognised as a significant and independent risk factor for all-cause, cardiovascular, and noncardiovascular mortality and fatal and non-fatal coronary heart disease and congestive heart failure is represented in $46 \%$ patients of this research. Smoking is a risk factor for mortality and coronary heart disease in patients with hypertension as well as with DM. However, there is no evidence that the relative risk of smoking is higher in people with diabetes than in people without DM. Because DM alone is a risk factor for morbidity and mortality, the absolute risk of smoking is usually higher in people with diabetes than in people without DM (17). The positive association between blood pressure, which is in this research represented in 69\% of patients, and CVD was well documented in recent studies $(18,19)$. Smoking is also associated with blood pressure level and CVD mortality (20). In addition to the above, recent studies revealed a significant relationship between the combined effects of smoking and blood pressure on CVD mortality (17).

In this research, $\mathrm{HCY}$ level is higher in females. This implies a contribution of DM to the elevation of $\mathrm{HCY}$ level in this population, which confirms the fact that females with diabetes are the group with the highest risk of developing CVD, and hospital mortality in female patients with AMI compared to males is significantly increased (28). In our study, female patients were older than males, which is in line with research Cui et al. (21). The females were postmenopausal when the protective vasodilating effect of endoge- nous estrogen is weak (22), which partly explains the increased risk observed in these patients. The action of estrogen in CVD in females is manifested through an increase in NO release leading to vasodilatation, in the regulation of prostaglandin synthesis and inhibition of epithelial smooth muscle cell proliferation. Due to the failure of these mechanisms in postmenopause, endothelial dysfunction occurs, with lipid deposition on the endothelium of blood vessels, ultimately favouring the development of atherosclerosis (23).

The available data in the literature on the association between CVD and hyperhomocysteinemia are contradictory; some suggest an association (11) while others do not, and explain it by the high HCY level in the general population (6). Contradictory results may be due to different selection of research participants, i.e. different inclusion and exclusion criteria in the study, different number of participants, methods used, genetic basis and different eating habits (24). Genetic basis, sufficient intake of vitamins B6, B12 and folic acid, as well as preserved renal function, are factors that directly affect HCY level (11) and should all be considered during assessment in any case.

Hyperuricemia is also known to be a critical factor in the development of CVD in the elderly, which is why early detection of UA can identify and prevent it. UA exerts its effects in different ways, which is why it can be associated with the occurrence and development of the disease (25). UA levels are elevated in patients with AMI compared with normal healthy individuals. UA levels are elevated in systemic hypertension, and diabetes mellitus patients with AMI (26), e.g. patients with hyperuricemia have an increased risk of developing type 2 DM (27). The described increased UA level in patients with AMI compared to the healthy control group (29) is confirmed in this research. Serum UA level in the males and females are higher than the reference range values to which a positive antioxidant effect is usually associated. In epidemiological and clinical studies, the effect of UA has been observed not only as an indicator of cardiovascular risk but also as a cause of endothelial dysfunction. Endothelial dysfunction is defined as a condition of impaired vascular homeostasis due to a disturbed balance of endothelial vasodilators and vasoconstrictors, leading to the progression of atherosclerosis.

In this research, HCY level, as a marker of oxidative stress was correlated with UA level, which has antioxidant activity in the body. The association between HCY and UA can be easily explained by hydrolysis of S-adenosyl HCY when adenosine is formed, which is further degraded to UA (24). This implies that every increase in $\mathrm{HCY}$ will result in an increase in UA. This was observed in our research on diabetic patients, but also healthy subjects, cardiovascular patients as well as stroke patients (30). In our study, a positive correlation between $\mathrm{HCY}$ and UA 
was observed. A review of biochemical characteristics in patients divided according to the UA level in tertiles revealed a significant difference in $\mathrm{HCY}$ level, i.e. patients with low UA level showed significantly reduced $\mathrm{HCY}$ level, which further confirms this connection. These results are consistent with the previous study (12). A study by Kiseljaković et al. (31) revealed the same association in patients with atherosclerotic vascular disease and healthy subjects. In addition to the proposed mechanisms, HCY increases arterial stiffness (32), reduces the possibility of methylation causing endothelial dysfunction as well as vascular smooth muscle cell proliferation, oxidative stress, NF$\kappa \mathrm{B}$ activation, inflammation, and inhibition of $\mathrm{NO}$ synthesis in the endothelium (24). It was also confirmed that the combined effect of hyperhomocysteinemia and hyperuricaemia has a stronger effect on these epithelial changes (12), suggesting the need to observe the synergistic action of HCY and UA in CVD in patients with type $2 \mathrm{DM}$.

The analysis of parameters distributed in tertiles according to UA level revealed a strong association of elevated UA level with a higher frequency of hypertension. Several previous epidemiological studies confirmed this association (33). However, it is still unclear, whether UA is an independent causal factor, a mediator, or just an indicator of the development of hypertension. Proposed mechanisms that are mainly based on research data obtained from animal models and cell cultures include endothelial damage, vascular inflammation, and activation of the reninangiotensin system. Briefly, hypertension results from the action of UA, which causes vasoconstriction in the kidney due to decreased NO synthesis in the endothelium, with activation of the renin-angiotensin system. Independently of these changes, UA causes microvascular damage to the kidneys over time (histologically similar to atherosclerosis), which further encourages the development of hypertension (33). Discovering the role of UA in the development of hypertension is complex because both UA and blood pressure are associated with renal function as well as other common metabolic disorders $(33,34)$. Therefore, we analysed whether UA and HCY are associated with glomerular filtration rate (eGFR). The association of UA with the renal function was confirmed by a strong negative correlation between UA and eGFR. Distribution of groups according to UA level in tertiles different eGFR level were also observed in the obtained subgroups. In this study, decreased eGFR values were observed in female subjects. Female gender, low eGFR, and high creatinine level on admission in coronary units are important prognostic factors for impaired cardiac function and increased mortality in the post-infarction period and can be used to assess risk in patients with $\mathrm{AMI}$ (35). In several smaller clinical studies, the effect of lowering UA on lowering blood pressure in patients with hypertension was observed $(33,36)$. This, however, suggests UA as a causal factor in the development of hypertension, especially in the early stages before the onset of significant endothelial damage (37). A negative correlation of HCY with eGFR was observed, which further confirms the association with the preservation of renal function. A decrease in eGFR is thought to cause a decrease in HCY secretion. Hyperhomocysteinemia was suggested as an important pathogenic factor leading to glomerular injury, dysfunction, and sclerosis (32). Increased oxidative stress and decreased antioxidant defence function caused by hyperhomocysteinemia were proven to be associated with the renal function (38). The observed negative correlation with eGFR suggests the importance of preserving renal function in the regulation of $\mathrm{HCY}$ and UA level.

Negative correlations were also observed between UA and $\mathrm{HbA} 1 \mathrm{c}$. A negative correlation is considered to indicate the existence of hyperinsulinemia in these patients, and UA is considered a good indicator of blood glucose level. However, an increase in UA compared with an increase in glucose is a characteristic of a healthy population and patients with prediabetes, but in type $2 \mathrm{DM}$, a decrease in UA was observed with an increase in $\mathrm{HbA} 1 \mathrm{c}$, which was found in this study as well. The reason for the reverse association is still unclear, but insulin is thought to be a factor influencing this association (21). Serum UA level will increase with an increased insulin level in patients with diabetes (39). Insulin causes the activation of the pentose phosphate pathway, which stimulates the biosynthesis and transformation of purines, as well as the synthesis of UA. At the same time, insulin causes an increase in UA reabsorption in the kidneys by stimulating the urate anion transporter on the proximal tubules, which ultimately causes an increase in serum level (40). At the same time, insulin causes a decrease in serum glucose level, and thus affects the levels of both parameters.

According to the results of our study, both $\mathrm{HCY}$ and UA are factors of atherosclerosis. Hence their action in the body should not be observed independently because their metabolism, as well as the effect on the cardiovascular system, show significant overlaps. Also, both of these markers can be used as markers of renal dysfunction in these patients.

Our study has several limitations. It is a singlecentre study with a relatively small group of patients. Control subjects without diabetes were not included in our study. Plasma levels of vitamin B and folate, both of which influence the plasma level of $\mathrm{HCY}$, were not measured.

In conclusion, this study indicates that a combined assessment of HCY and UA, as well as a regression analysis, can identify high-risk patients at an earlier stage, and appropriate interventions can influence a better outcome in such patients. Identification of hyperhomocysteinemia as a risk factor, especially in 
female patients, is of great importance for the diabetic population primarily because of primary and secondary prevention in these patients involving the use of a number of vitamins such as folic acid, vitamin B12 and pyridoxine that directly affect serum $\mathrm{HCY}$ level. Therefore, further research studying the impact of the use of these vitamins on the reduction of serum $\mathrm{HCY}$ level in the diabetic population of Bosnia and Herzegovina would be of multiple importance. Also, the use of $\mathrm{HCY}$ as a marker in prediabetes and diabetes would contribute to the establishment of sub-

\section{References}

1. Mendis S, Thygesen K, Kuulasmaa K, Giampaoli S, Mähönen $M, \mathrm{Ngu}$ Blackett $\mathrm{K}$ et al. Writing group on behalf of the participating experts of the WHO consultation for revision of WHO definition of myocardial infarction. World health organisation definition of myocardial infarction: 2008-09 revision. Int J Epidemiol 2011; 40: 139-46.

2. Matheus AS, Tannus LR, Cobas RA, Palma CC, Negrato CA, Gomes MB. Impact of diabetes on cardiovascular disease: an update. Int J Hypertens 2013; 653789.

3. Ballotari P, Ranieri SC, Luberto F, Caroli S, Greci M, Giorgi Rossi $P$ et al. Sex differences in cardiovascular mortality in diabetics and nondiabetic subjects: a population-based study (Italy). Int J Endocrinol 2015; 2015: 914057

4. Pooja S, Pradhan R, Lekharu R. A study of serum homocysteine levels in acute myocardial infarction patients. Int J Curr Res 2014; 6: 08: 8171-3.

5. Alam N, Khan HI, Chowdhury AW, Haque MS, Ali MS, Sabah KM et al. Elevated serum homocysteine level has a positive correlation with serum cardiac troponin I in patients with acute myocardial infarction. Bangladesh Med Res Counc Bull 2012; 38: 9-13.

6. Iqbal MP, Ishaq M, Kazmi KA, Yousuf FA, Mehboobali N, Ali SA et al. Role of vitamin B6, B12 and folic acid on hyperhomocysteinemia in a Pakistani population of patient with acute myocardial infarction. Nutr Metab Cardiovasc Dis 2005; 15: 100-8.

7. Joshi M, Baipadithaya G,1 Balakrishnan A, Hegde M, Vohra $M$, Ahamed $R$ et al. Elevated homocysteine levels in type 2 diabetes induce constitutive neutrophil extracellular traps. Sci Rep 2016; 6: 36362.

8. Platt DE, Hariri E, Salameh P, Merhi M, Sabbah N, Helou $M$ et al. Type II diabetes mellitus and hyperhomocysteinemia: a complex interaction. Diabetol Metab Syndr 2017; 9: 19 .

9. Kumar J, Ingelsson E, Lind L, Fall T. No Evidence of a Causal Relationship between Plasma Homocysteine and Type 2 Diabetes: A Mendelian Randomization Study. Front Cardiovasc Med 2015; 2: 11.

10. Čaušević A, Semiz S, Macić-Džanković A, Cico B, Dujić $\mathrm{T}$, Malenica $\mathrm{M}$ et al. Relevance of uric acid in progression clinical CVD and suggest the need to take preventive measures before a possible occurrence of infarction or stroke.

\section{Conflict of interest statement}

The authors have no conflicts of interest to declare. The authors give consent to the submission and publication of the work. Authors disclose no relationship to any organization or industrial manufacture in any material discussed.

of type 2 diabetes mellitus. Bosn J Basic Med Sci 2010; 10(1): 54-9.

11. Čolak E, Pap D, Nikolić Lj, Vicković S. The impact of obesity to antioxidant defense parameters in adolescents with increased cardiovascular risk. J Med Biochem 2020; 39: 346-54.

12. Cohen E, Levi A, Vecht-Lifshitz SE, Goldberg E, Garty M, Krause IA. Assessment of a possible link between hyperhomocysteinemia and hyperuricemia. J Investig Med 2015; 63(3): 534-8.

13. American Diabetes Association. Classification and Diagnosis of Diabetes. Diabetes Care 2015; 38(1): 8-16.

14. Marković Boras M, Čaušević A, Brizić I, Mikulić I, Vasilj M, Jelić-Knezović N. A relation of serum homocysteine, uric acid and C-reactive protein level in patients with acute myocardial infarction. Med Glas (Zenica) 2018; 15(2): $101-8$.

15. Yokoi Y, Kondo T, Okumura N, Shimokata K, Osugi S, Maeda $\mathrm{K}$ et al. Serum uric acid as a predictor of future hypertension: Stratified analysis based on body mass index and age. Prev Med 2016; 90: 201-6.

16. Moshki M, Zareie M, Hashemizadeh H. Sex differences in Acute Myocardial Infarction. Nurs Midwifery Stud 2015; 4(1): e22395.

17. Fagard R. Smoking amplifies cardiovascular risk in patients with hypertension and diabetes. Diabetes care 2009; 32(2): 429-31.

18. Wu CY, Hu HY, Chou YJ, Huang N, Chou YC, Li CP. High Blood Pressure and All-Cause and Cardiovascular Disease Mortalities in Community-Dwelling Older Adults. Medicine (Baltimore) 2015; 94(47): e2160.

19. Wan E, Yu E, Chin W, Fong D, Choi E, Lam C. Association of Blood Pressure and Risk of Cardiovascular and Chronic Kidney Disease in Hong Kong Hypertensive Patients. Hypertension 2019; 74(2): 331-40.

20. Tan J, Zhang X, Wang W, Yin P, Guo X, Zhou M. Smoking, Blood Pressure, and Cardiovascular Disease Mortality in a Large Cohort of Chinese Men with 15 Years Follow-up. Int J Environ Res Public Health 2018; 15(5): 1026.

21. Cui Y, Bu H, Ma X, Zhao S, Li X, Lu S. The Relation 
between Serum Uric Acid and HbA1c Is Dependent upon Hyperinsulinemia in Patients with Newly Diagnosed Type 2 Diabetes Mellitus. J Diabetes Res 2016; 2016: 7184123.

22. Boukhris M, Tomasello SD, Marzà F, Bregante S, Pluchinotta FR, Galassi AR. Coronary Heart Disease in Postmenopausal Women with Type II Diabetes Mellitus and the Impact of Estrogen Replacement Therapy: A Narrative Review. Int J Endocrinol 2014; 2014: 413920.

23. Mehta LS, Beckie TM, DeVon HA, Grines CL, Krumholz $H M$, Johnson $M N$ et al. Acute Myocardial Infarction in Women: A Scientific Statement From the American Heart Association. Circulation 2016; 133(9): 916-47.

24. Cacciapuoti F. Hyper-homocysteinemia Inducing Hyperuricemia: What are the Mechanisms? J Rheum Dis 2017; 24: 127-30.

25. Muiesan ML, Agabiti-Rosei C, Paini A, Salvetti M, 2016. Uric Acid and Cardiovascular Disease: An Update. Eur Cardiol 2016; 11(1): 54-9.

26. Jang S, Jeong M, Song J, Park K, Sim D, Kim J. Clinical impact of serum uric acid in patients with acute myocardial infarction. JACC 2014; 63(12): 239.

27. Lv Q, Meng XF, He FF, Chen S, Su H, Xiong J et al. High serum uric acid and increased risk of type 2 diabetes: a systemic review and meta-analysis of prospective cohort studies. PLoS One 2013; 8(2): e56864.

28. Wijnbergen I, Tijssen J, van 't Veer M, Michels R, Pijls $\mathrm{NH}$. Gender differences in long-term outcome after primary percutaneous intervention for ST-segment elevation myocardial infarction. Catheter Cardiovasc Interv 2013; 82(3): 379-84.

29. Nadkar MY, Jain VI. Serum uric acid in acute myocardial infarction. J Assoc Physicians India 2008; 56: 759-62.

30. Hong YS, Lee MJ, Kim KH, Lee SH, Lee YH, Kim BG, et al. The $\mathrm{C} 677$ mutation in methylene tetrahydrofolate reductase gene: correlation with uric acid and cardiovascular risk factors in elderly Korean men. J Korean Med Sci 2004; 19: 209-13.

31. Kiseljaković E, Valjevac A, Hasić S, Nakas-lćindić E, Dzubur A, Jadrić R. Association of homocysteine with tra- ditional and non-traditional risk factors in patients with atherosclerotic vascular disease. Med Glas (Zenica) 2011; 8(1): 126-33.

32. Fu S, Luo L, Ye P, Xiao W. Multimarker analysis for new biomarkers in relation to central arterial stiffness and hemodynamics in a Chinese community-dwelling population. Angiology 2015; 66(10): 950-6.

33. Stewart DJ, Langlois S, Noone D. Hyperuricemia and Hypertension: Links and Risks. Integr Blood Press Control 2019; 12: 43-62.

34. Fu S, Yao Y, Zhao Y, Luan F. Relationships of Hyperhomocysteinemia and Hyperuricemia With Metabolic Syndrome and Renal Function in Chinese Centenarians. Front Endocrinol 2018; 9: 502.

35. Sederholm Lawesson S, Alfredsson J, Szummer K, Fredrikson $M$, Swahn E. Prevalence and prognostic impact of chronic kidney disease in STEMI from a gender perspective: data from the SWEDEHEART register, a large Swedish prospective cohort. BMJ Open 2015; 5: e008188.

36. Noman A, Ang DSC, Ogston S, Lang CC, Struthers AD. Effect of high-dose allopurinol on exercise in patients with chronic stable angina: a randomised, placebo controlled crossover trial. Lancet 2010; 375: 2161-7.

37. Loeffler LF, Navas-Acien A, Brady TM, Miller ER, Fadrowski JJ. Uric acid level and elevated blood pressure in US adolescents: National Health and Nutrition Examination Survey, 1999-2006. Hypertension 2012; 59(4): 811-17.

38. Ostrakhovitch EA, Tabibzadeh S. Homocysteine in chronic kidney disease. Adv Clin Chem 2015; 72: 77-106.

39. Gill A, Kukreja S, Malhotra N, Chhabra N. Correlation of the serum insulin and the serum uric acid levels with the glycated haemoglobin levels in the patients of type 2 diabetes mellitus. J Clin Diagn Res 2013; 7(7): 1295-7.

40. Toyoki D, Shibata S, Kuribayashi-Okuma E, Xu N, Ishizawa K, Hosoyamada M. Insulin stimulates uric acid reabsorption via regulating urate transporter 1 and ATPbinding cassette subfamily $\mathrm{G}$ member 2 . Am J Physiol Renal Physiol 2017; 313(3): 826-34. 